\title{
FAKTOR-FAKTOR YANG MEMPENGARUHI PERILAKU ADAPTIF ANAK USIA DINI
}

\author{
Rizqiyah Ratu Balqis \\ Institut Agama Islam Al-Falah As-sunniyyah Kencong \\ Email: Rizqiyahratubalqis@gmail.com
}

\begin{abstract}
Adaptive behavior is one of the abilities that must be possessed by every individual to live a good social life. Adaptive behavior will influence children's successful in their social life. Therefore, this paper aims to reveal the various factors that can influence early childhood behavior. The factors that influence the adjustment process include: physical condition, personality, education, environment, religion and culture.
\end{abstract}

Keywords: Adaptive Behavior, Early Childhood

\section{PENDAHULUAN}

Masa kanak-kanak merupakan masa penting dalam perkembangan hidup manusia. Hal ini dikarenakan masa kanak-kanak merupakan masa paling awal dalam rentang khidupan yang akan menetukan perkembangan pada tahap selanjutnya. Menurut Heru Astikasari (2006), dalam proses tumbuh kembangnya, seorang anak akan melalui tahap perkembangan dengan tugas perkembangan yang berbeda-beda. keberhasilan pencapaian suatu tugas perkembangan di suatu tahap akan membantu kelancaran tahap berikutnya. Dengan demikian, anak dikatakan berkembang secara normal apabila anak dapat menyelesaikan tugas yang harus dijalaninya pada masa tersebut. Secara umum, kesesuaian antara perkembangan anak dengan apa yang harus dicapainya terlihat melalui perilaku adaptifnya.

Perilaku adaptif merupakan suatu tingkat dimana individu mampu berperilaku sesuai standar kebebasan personal dan standar dalam merespon lingkungan seperti yang diharapkan oleh kelompok budaya dan usia tertentu (Sattler, 1992). Perilaku adaptif merupakan performansi tipikal seseorang dalam aktivitasnya sehari-hari yang memerlukan kecakapan sosial dan personal (Markusic, 2012). Menurut Rahayu (2010), perilaku adaptif adalah kemampuan seseorang untuk mampu menyesuaikan diri dengan norma atau standar yang berlaku di lingkungannya. Jika seseorang mampu berperilaku sesuai dengan norma yang berlaku di lingkungannya, maka dapat dikatakan bahwa individu tersebut mempunyai perilaku adaptif yang baik. Tidak semua orang mampu berperilaku secara adaptif karena perilaku adaptif dipengaruhi oleh lingkungan, intelegensi, kecerdasan emosi dan dukungan sosial.

Perilaku adaptif merupakan salah satu kemampuan yang harus dimiliki oleh setiap individu untuk menjalani kehidupan bermasyarakat dengan baik. Upaya membina dan 


\section{Rirqiyah Ratu Balqis}

mengembangkannya pada setiap individu bukanlah sesuatu yang mudah, terlebih lagi bagi penyandang autis. Manusia sebagai makhluk sosial, ia menggabungkan dirinya dengan orang lain di dalam kegiatan -kegiatannya. Semuanya ini merupakan bawaan (innate) dan bersifat subyektif. Sekalipun demikian, ia tidak muncul secara spontan melainkan harus ditumbuhkembangkan melalui bimbingan dan latihan. melalui bimbingan dan latihan yang memadai, penyandang autis akan termotivasi untuk menguasai situasi hidupnya, sehingga mereka merasa puas dapat menunjukkan keunggulannya dalam rangka menghilangkan perasaan rendah dirinya, keterasingannya, dan kekurang percayaan pada dirinya. Dengan demikian, minat sosial (social interest) yang ada pada dirinya dapat berkembang dengan baik. Oleh sebab itu, penulis ingin mengungkap Apa saja faktor-faktor yang mempengaruhi perkembangan perilaku adaptif anak usia dini

\section{PEMBAHASAN}

\section{Faktor-faktor yang mempengaruhi perkembangan perilaku adaptif anak usia dini}

Menurut Scheneiders (dalam Ali dan Asrori, 2009: 181-189) setidaknya ada lima faktor yang dapat mempengaruhi proses penyesuaian diri yaitu:

a. Kondisi fisik

Kondisi fisik Berpengaruh kuat terhadap proses penyesuaian diri seorang anak. Karena jika kondisi fisik anak tersebut tidak memiliki fungsi yang sama dengan lainnya, maka anak tersebut akan merasa terkucilkan dan menutup diri sehingga anak tersebut akan mengalami hambatan dalam perkembangan perilaku adaptifnya.

Aspek-aspek berkaitan kondisi fisik yang dapat mempengaruhi penyesuaian diri remaja sebagai berikut:

1. Hereditas dan konstitusi fisik

Dalam mengidentifikasi pengaruh hereditas terhadap penyesuaian diri, lebih digunakan pendekatan fisik karena hereditas dipandang lebih dekat dan tak terpisahkan dari mekanisme fisik. Dari sini berkembang prinsip-prinsip umum bahwa semakin dekat kapasitas pribadi, sifat, atau kecenderungan berkaitan dengan konstitusi fisik maka akan semakin besar pengaruhnya terhadap penyesuaian diri.

2. Sistem utama tubuh

Sistem utama tubuh memiliki pengaruh terhadap penyesuaian diri adalah sistem syaraf, kelenjar dan otot. Sistem syaraf yang berkembang dengan normal dan sehat merupakan syarat mutlak bagi fungsi-fungsi psikologis agar dapat berfungsi maksimal yang akhirnya berpengaruh baik pula kepada penyesuaian diri individu. Dengan kata lain, fungsi yang memadai dari sistem syaraf merupakan kondisi umum yang diperlukan bagi penyesuaian diri yang baik.

3. Kesehatan fisik

Penyesuaian diri seseorang akan lebih mudah dilakukan dan dipelihara dalam kondisi fisik yang sehat daripada yang tidak sehat. Kondisi fisik yang sehat dapat menimbulkan penerimaan diri, percaya diri, harga diri dan sejenisnya yang akan menjadi kondisi yang sangat menguntungkan bagi proses penyesuaian diri. Sebaliknya, kondisi fisik yang tidak sehat dapat menyebabkan perasaan rendah diri, kurang percaya diri, atau bahkan menyalahkan diri sehingga akan berpengaruh kurang baik bagi proses penyesuaian diri. 
b. Kepribadian

Unsur-unsur kepribadian yang penting pengaruhnya terhadap penyesuaian diri adalah (a) Kemauan dan kemampuan untuk berubah, (b) Pengaturan diri, (c) Realisasi diri dan (d) Intelegensi. Masingmasing unsur dapat dijelaskan sebagai berikut;

1. Kemauan dan kemampuan untuk berubah

Kemauan dan kemampuan untuk berubah merupakan karakteristik kepribadian yang pengaruhnya sangat menonjol terhadap proses penyesuaian diri. Sebagai suatu proses yang dinamis dan berkelanjutan, penyesuaian diri membutuhkan kecenderungan untuk berubah dalam bentuk kemauan, perilaku, sikap dan karakteristik sejenis lainnya. Oleh sebab itu, semakin kaku dan tidak ada kemauan dan kemampuan untuk merespon lingkungan, semakin besar kemungkinannya untuk mengalami kesulitan dalam penyesuaian diri.

2. Pengaturan diri

Pengaturan diri sama pentingnya dengan proses penyesuaian diri dan pemeliharaan stabilitas mental, kemampuan untuk mengatur diri dan mengarahkan diri. Kemampuan mengatur diri dapat membantu individu dari keadaan penyimpangan kepribadian. Kemampuan pengaturan diri dapat mengarahkan kepribadian normal mencapai pengendalian diri dan realisasi diri.

3. Realisasi diri

Kemampuan pengaturan diri mengimpilkasikan potensi dan kemampuan ke arah realisasi diri. Proses penyesuaian diri dan pencapaian hasilnya secara bertahap sangat erat kaitannya dengan perkembangan kepribadian. Jika perkembangan kepribadian berjalan normal sepanjang masa kanak-kanak dan remaja, di dalamnya tersirat potensi laten dalam bentuk sikap, tanggungjawab, penghayatan nilai-nilai, penghargaan diri dan lingkungan serta karakteristik lainnya menuju pembentukan kepribadian dewasa. Semua itu, unsur-unsur penting yang mendasari realisasi diri.

4. Intelegensi

Kemampuan pengaturan diri sesungguhnya muncul tergantung pada kualitas dasar lainnya yang penting peranannya dalam penyesuaian diri, yaitu kualitas intelegensi. Tidak sedikit, baik buruknya penyesuaian diri seseorang ditentukan oleh kapasitas intelektualnya atau intelegensinya. Intelegensi sangat penting bagi perolehan perkembangan gagasan, prinsip dan tujuan memainkan peranan penting dalam proses penyesuaian diri.

c. Pendidikan

1. Belajar

Kemauan belajar merupakan unsur penting dalam diri individu karena pada umumnya respon-respon dan sifat kepribadian yang diperlukan bagi penyesuaian diri yang menyerap kedalam proses individu melalui proses belajar.

2. Pengalaman

Ada dua pengalaman yang mempengaruhi individu da dirasakan sebagai sesuatu yang memiliki nilai signifikan terhadap proses penyesuaian diri, yaitu (1) pengalaman yang menyehatkan, (2) pengalaman traumatik. Pengalaman yang menyehatkan adalah peristiwa-peristiwa yang dialami oleh individu bahkan dirasa mengenakan, mengasyikan dan aman mengulanginya kembali. Adapun pengalaman traumatik adalah peristiwa-peristiwa yang dialami oleh individu dan 


\section{Rizqiyah Ratu Balqis}

dirasakan sebagai sesuatu yang sangat tidak mengenakan, menyedihkan atau bahkan sangat menyakitkan sehingga individu tersebut sangat tidak ingin peristiwa itu terulang kembali. Individu yang mengalami pengalaman traumatik akan cenderung ragu-ragu, kurang percaya diri, gamang, rendah diri, atau bahkan merasa takut ketika harus menyesuaikan diri dengan lingkungan yang baru.

3. Latihan

Latihan merupakan proses belajar yang diorientasikan kepada perubahan keterampilan atau kebiasaan, penyesuaian diri sebagai suatu proses yang kompleks yang mencangkup didalamnya proses psikologis dan sosiologis maka memerlukan latihan yang sungguhsungguh agar mencapai hasil penyesuaian diri yang baik. Tidak jarang sesorang yang sebelumnya memiliki kemampuan penyesuaian diri yang kurang baik dan kaku, tetapi karena melakukan latihan secara sungguh-sungguh, akhirnya lambat laun menjadi bagus dalam sikap penyesuaian diri dengan lingkungan baru.

4. Determinan diri

Berkaitan erat dengan penyesuaian diri adalah bahwa sesungguhnya individu itu sendiri harus menentukan dirinya sendiri untuk melakukan penyesuaian diri. Ini menjadi penting karena determinasi diri merupakan faktor yang sangat kuat yang digunakan untuk kebaikan dan keburukan, untuk mencapai penyesuaian diri yang tuntas, atau bahkan untuk merusak dirinya sendiri.

d. Lingkungan

Faktor lingkungan berpegaruh terhadap penyesuaian diri meliputi;

1. Lingkungan keluarga

Lingkungan keluarga merupakan lingkungan utama yang sangat penting atau bahkan tidak ada yang lebih penting dalam kaitannya dengan penyesuaian diri individu.

2. Lingkungan sekolah

Sebagaimana lingkungan keluarga, lingkungan sekolah juga dapat menjadi kondisi yang memungkinkan berkembang dan terhambatnya proses perkembangan penyesuaian diri. Pada umumya, sekolah dipadang sebagai media yang sangat berguna untuk memengaruhi kehidupan dan perkembangan intelektual, sosial, nilai-nilai, sikap dan moral siswa.

3. Lingkungan masyarakat

Lingkungan masyarakat juga menjadi faktor yang dapat berpengaruh terhadap perkembangan penyesuaian dirinya. Kenyataan menunjukan kecenderungan ke arah penyimpangan perilaku dan kenakalan remaja sebagai salah satu bentuk penyesuaian diri yang tidak baik, berasal dari pengaruh lingkungan masyarakat.

e. Agama serta budaya

Agama berkaitan erat dengan faktor budaya. Agama memberikan sumbangan nilai-nilai, keyakinan, praktik-praktik yang memberi makna sampai mendalam, tujuan, kesimbangan dan kestabilan dalam hidup individu. Faktor agama memiliki sumbangan yang berarti terhadap perkembangan penyesuaian diri individu. Selain agama budaya juga merupakan faktor yang sangat berpengaruh terhadap kehidupan 
individu hal ini terlihat jika dilihat dari adanya karakteristik yang diwariskan kepada individu melaui berbagai media satu diantaranya lingkungan sekolah.

\section{PENUTUP}

Kepribadian, sifat dan fisik manusia akan memberikan pengaruh yang sangat besar bagi perkembangan proses penyesuaian dirinya. Selain itu, untuk memaksimalkan fungsi psikologis manusia, maka sangat di perlukan kondisi sistem syaraf yang berkembang secara normal dan sehat, sehingga dengan sistem syaraf yang normal dan sehat akan sangat mempengaruhi proses penyesuaian diri. Kesehatan fisik juga sangat berpengaruh pada proses penyesuaian diri, kondisi fisik yang tidak sehat dapat menyebabkan perasaan rendah diri, kurang percaya diri, atau bahkan menyalahkan diri sehingga akan berpengaruh kurang baik bagi proses penyesuaian diri. Dan juga, kemampuan pengaturan diri dapat mengarahkan kepribadian normal mencapai pengendalian diri dan realisasi diri. 
Rirqiyah Ratu Balqis

\section{DAFTAR PUSTAKA}

Astikasari, Heru. 2006. Perilaku Adaptif Anak dalam Playgroup. Anima, Indonesian Psychological Journal, Vol. 22, No. 1, 86-91

Makusic, M. (2012, Februari 14). The vineland adaptive behavior scale and special needs students. Diunduh dari http://www.brighthubeducation.com/specialedlaw/13506-the-vineland-adaptive-behavior-scale/ tanggal 25 Maret 2021.

Rahayu, E. (2010). Perilaku adaptif tunagrahita dewasa ditinjau dari klasifikasi tunagrahita. Semarang : Universitas Katolik Soegijapranata.

Sattler, J. M. (1992). Assesment of children. San Diego: Jerome M. Sattler Publisher, Inc.

http://webcache.googleusercontent.com/search?q=cache:j1UeepLCMXcj:digilib.unila.ac.i $\mathrm{d} / 5171 / 14 / \mathrm{BAB} \% 2520 \mathrm{II} \cdot \mathrm{pdf}+\& \mathrm{~cd}=8 \& \mathrm{hl}=$ en\&ct $=\operatorname{clnk} \& \mathrm{gl}=\mathrm{id}$ 